MARIA DA CONCEIÇÃO MEIRELES PEREIRA

\title{
IBERISMO E NACIONALISMO EM PORTUGAL DA REGENERAÇÃO À REPÚBLICA. ENTRE UTOPIA E DISTOPIA
}

Separata da Revista de História das Ideias, Vol. 31

Faculdade de Letras

Coimbra

2010 



\section{IBERISMO E NACIONALISMO EM PORTUGAL DA REGENERAÇÃO À REPÚBLICA. ENTRE UTOPIA E DISTOPIA**}

Primeiro os conceitos. Segundo Lyman Sargent ${ }^{(1)}$, o utopismo remete genericamente para o sonho social. A utopia ou eutopia descrevem uma sociedade não existente, cujo autor pretende que o leitor a veja como consideravelmente melhor do que aquela em que vive. Inversamente, o objectivo na distopia é que a sociedade descrita seja entendida como substancialmente pior do que a vivida pelo leitor. Já na anti-utopia, pretende-se que a sociedade imaginada seja uma crítica ao utopismo ou a una eutopia particular.

Os séculos XVIII e XIX assistiram à emergência do utopismo sob uma nova forma "científica", afirma-se a relação entre história e utopia, tomando como referência o grande mito político da Revolução Francesa que estabelece uma série de relacionamentos entre utopismo e ideias filosóficas, movimentos sociais, correntes ideológicas e imaginários colectivos, constituindo-se como um momento histórico em que o desejo invade a política. As utopias tornavam-se reais, eram modelos

* Faculdade de Letras da Universidade do Porto/CEPESE.

** Este texto tem como base (sem o suporte iconográfico) a lição síntese apresentada na Faculdade de Letras da Universidade do Porto, no âmbito das provas de agregação, em 17 de Julho de 2007, da qual foi arguente o Professor Fernando Catroga a quem se agradecem os incentivos recebidos.

(1) "The Three Faces of Utopianism Revisited", Utopian Studies, vol. 5, n," 1, 1994, p. 9. 
políticos com vista à resolução da crise, abarcando a dinâmica sócio-cultural e acolhendo as aspirações colectivas num horizonte de temores e esperanças. Esta "historicização" da utopia resulta dos conceitos de Progresso e Ciência que vão alterar a estrutura das utopias: é o tempo, e já não o lugar, o seu elemento de representação. A utopia transforma-se em ucronia, ou melhor, eucronia, o lugar de felicidade e perfeição que é, doravante, no futuro e que se prende com a cosmovisão optimista das Luzes. Assim, a eucronia é o produto da lógica iluminística que associa a ideia de inevitabilidade do progresso à da infinita perfectibilidade humana ${ }^{(2)}$. O discurso eucrónico, ao situar a sociedade ideal no futuro, pressupõe que determinadas aç̧ões - sobretudo a nível político - se concretizarão, nomeadamente no próprio país do utopista e, por força do Progresso, afectará todos os outros atingindo uma dimensão universal.

Como explica Bronislaw Baczko, a grande massa de textos utópicos era então constituída por livros, ensaios, jornais, etc., que expunham "sistemas" de reformas sociais apoiados numa crítica mais ou menos radical da sociedade contemporânea, mas cada vez mais avançados como solução ou resposta à crise, pelo que essas representações da sociedade remetiam para um "futuro apresentado como estando ao alcance da mão"; futuro imaginado, decerto, mas de modo algum quimérico pois o seu advento seria assegurado pelo Progresso, prevendo uma sociedade composta de homens livres que se regem pela razão, sem guerras nem conflitos, gozando dos benefícios da civilização já que o aperfeiçoamento moral do homem e a racionalização das instituições terão por resultado a eliminação dos preconceitos e o aumento da felicidade ${ }^{(3)}$.

A questão ibérica (re)suscitada em Portugal por meados do Oitocentos decorre de duas tendências aparentemente contraditórias mas ambas em voga na época: o utopismo das Luzes, assente nas ideias de pacifismo e de fraternidade universal; e a valorização da especificidade típica do Romantismo com o advento do Estado-Nação e consequente movimento das nacionalidades. Por isso, o estudo português fundador sobre a temática iberista da autoria de Fernando Catroga, em 1985, assumia o título Nacionalismo e Ecumenismo, sublinhando o "dilema em que

(2) Vita Fortunati, "History", in Vita Fortunati and Raymond Trousson (eds.) Dictionary of Literary Ltopias, Paris, Honoré Champion Éditeur, 2000, pp. 288-289.

(3) Bronislaw Baczko, "Utopia", in Anthropos-Homem, Enciclopédia Einaudi, vol. 5, Lisboa, IN-CM, pp. 365-366. 
se debatia o ideal ibérico: salvaguardar a identidade nacional sem bloquear a integração de Portugal nessa caminhada para a edificação da cosmopolis"(4).

Sabendo-se que as teses iberistas não conheceram concretização histórica, derramando-se apenas, embora intensamente, nos imaginários sociais, devem ser abordadas à luz da história cultural. Assim, procurar-se-á evidenciar algumas representações apologéticas do ideal ibérico, de natureza utópica, assim como outras de sentido contrário, em que releva a dimensão de anátema, portanto de carácter anti-utópico ou distópico. O período cronológico em análise estende-se da Regeneração à República. O terceiro quartel de Oitocentos corresponde ao tempo forte da polémica, entre a publicação de obras que despoletam a questão e o fim da interinidade espanhola, assistindo-se ao crescendo da reacção nacionalista portuguesa; mas, posteriormente, a crise do ultimato e a política de Afonso XIII, bem como o contexto internacional e a instauração da República Portuguesa suscitaram vagas de idêntico teor polemista. Ainda em 1915, as conferências da Liga Naval que os integralistas lusitanos realizaram viriam a ser publicadas sob o título A União lbérica.

As origens desta polémica, como explicou Sampaio Bruno ${ }^{(5)}$, mergulham no emblemático ano de 1848, em plena "primavera dos povos", num ambiente utópico portanto, quando 400 espanhóis e portugueses emigrados em Paris fundaram o Clube Democrático Ibérico e percorreram as ruas da cidade aclamando a união peninsular e empunhando uma bandeira com os emblemas da Ibéria ${ }^{(6)}$. Embora este ideal tenha sido esporadicamente defendido pela imprensa republicana daquela década, a questão é despoletada em finais de $1851 \mathrm{com}$ a publicação da obra do espanhol Sinibaldo de Mas, A Ibéria, que advogava a união pacífica dos dois países sob a fórmula monárquica e enfatizava as vantagens

(4) Fernando Catroga, "Nacionalismo e Ecumenismo. A Questão Ibérica na Segunda Metade do Século XIX", Revista Cultura História e Filosofia, Lisboa, vol. IV, 1985, p. 423.

(5) Sampaio Bruno, Os Modernos Publicistas Portugueses, Porto, Livraria Chradron de Lello \& Irmão Editores, [1906] 1987, p. 80.

(6) Antonio Moliner Prada, "La Federación Ibérica y la Revolución de 1848", Ler História, Lisboa, n"16, 1989, p. 125; Pierre Rivas, "Utopie Ibérique et Idéologie d'un Fédéralisme Social Pan-Latin", in Actes du Colloque Lltopie et Socialisme an Portugal au XIXe Siècle, Paris, 10-13 Janvier 1979. Paris, Fondation Calouste Gulbenkian, Centre Culturel Portugais, 1982, p. 320. 
económicas decorrentes para Portugal. Muito lida e comentada, foi amplamente difundida por três edições portuguesas e seis espanholas, sucessivamente corrigidas e aumentadas, sempre profusamente ilustradas ${ }^{(7)}$.

À semelhança de todos os textos que vieram a ser publicados em defesa desta ideia, a dimensão eucrónica imperava, como sugere a figura "Sinopse da História da Península desde a Invasão dos Árabes até Hoje" que inclui 42 pequenos mapas da península, interrogando-se no último sobre a data em que se viria a cumprir a Ibéria. $O$ tradutor desta obra e autor do célebre prólogo foi Latino Coelho que aí patenteou a sua crença na grande federação da Europa, geradora de paz e equilibrio, ansiando pela "diminuição progressiva do número dos estados independentes". Cada fusão racional e espontânea entre povos com afinidades repreentava o apaziguamento e reconciliação entre eles, o desarmamento de dois exércitos, um novo triunfo da humanidade, enfim, um degrau mais galgado na escala da civilização. Desejava um processo de fusão que assegurasse a liberdade e progresso dos dois povos peninsulares sem tiranizar Portugal, que deveria começar pelas relações intelectuais, seguida das económicas, com o estabelecimento de um zollverein pleno. A obra parecia-lhe, pois, aconselhável já que encerrava "o único porvir feliz que resta[va] aos habitantes de Portugal".

Por sua vez, José Félix Henriques Nogueira, fundamental teórico precursor do republicanismo português, idealizou uma federação de municípios que seria completada, a nível externo, com a federação dos povos ibéricos. Nos seus Estudos sobre a Reforma em Portugal, também de 1851, explicava a excelência desta opção que deixava incólume a individualidade nacional e garantia a protecção e felicidade dos povos. A federação - "contrato nobre, equitativo, vantajoso" - proporcionava um aumento extraordinário de força, riqueza e bem-estar. A futura Federação Peninsular deveria obedecer à divisão provincial já consagrada pelo tempo e pela tradição, sendo constituído por quinze estados: Portugal e as catorze províncias espanholas (Galiza, Astúrias, Biscaia, Navarra, Catalunha, Aragão, Valência, Múrcia, Granada, Andaluzia, Estremadura, Castela-a-Nova, Castela-a-Velha e Leão). Esta fragmentação da Espanha reflecte o desejo de destruir a hegemonia política castelhana sobre as

(7) Maria da Conceição Meireles Pereira, "Sinibaldo de Mas: el diplomático español partidario del iberismo", Anuario de Derecho Internacional, Pamplona, Servicios de Publicaciones de la Universidad de Navarra, XVII, 2001, pp. 351-370. 
restantes regiões com as quais Portugal estabeleceria um contrato político, formando-se uma grande nação peninsular - "a Ibéria dos Povos".

O debate estava, pois, lançado. A partir daqui a polémica instala-se. A defesa da utopia ibérica assume duas fórmulas predominantes. A monárquica unitária que previa a união peninsular sob uma coroa única, punha a tónica na restauração da importância da Península no concerto das nações e na ideia de prosperidade económica, enfim na promessa do "imenso porvir de grandeza e glória", para utilizar as palavras de Carlos José Caldeira ${ }^{(8)}$, e a republicana federalista que à nostalgia das antigas autonomias locais - municípios, províncias, fueros - mesclava a doutrina federativa colhida nos exemplos dos Estados Unidos da América e da Suíça.

Apesar da falta de consenso e certezas quanto à arquitectura da federação peninsular (como o número de estados, fragmentação ou preservação do território português, etc.), esta via federalista inspirará todo o pensamento republicano e progressista de oitocentos, confiante de que a livre associação dos povos encontraria os seus caminhos.

Tal optimismo ressalta das palavras finais do ensaio de Joaquim Maria da Silva que em 1854 previa o estabelecimento dos Estados Unidos da Ibéria("): "Felizes os que então viverem! Beneméritos da humanidade os que concorrerem com os seus esforços e vontades para o alcance e realização dessa idade de ouro, de paz, de fraternidade".

O utopismo deste açoriano previa patamares superiores de entendimento supranacional pois considerava que mais do que a união peninsular, a missão dos povos providencialmente postos à entrada da Europa consistia em começar "a grande reforma do género humano", isto porque à sua união juntar-se-iam os irmãos da antiga América espanhola e portuguesa e, depois, viriam as outras nações, uma a uma, "até que o género humano se funda em uma só família com uma só religião, com uma só língua, com uma só lei".

(6) Apontamentos duna Viagem de Lisboa à China, Lisboa, Tip. de Castro \& Irmão, 1852-53, vol. 2, p. 287. Refira-se que quer os títulos quer as transcriçōes se apresentam en grafia actualizada.

(9) Maria da Conceição Meireles Pereira (edição de texto, introdução e notas), Felizes os que então viverem! Estados Unidos da lbéria - uma eucronia federativa de Joaquim Maria da Silva, Vila Nova de Famalicão, Ediçōes Quasi / FLUP, Colecção Biblioteca das Utopias, 2006. 
O ideal ibérico assumia, decisivamente, a forma de un utopismo quase messiânico, que resolvia os problemas candentes do país, nomeadamente económicos e políticos, e respondia também às aspirações humanitárias e filosóficas de gerações mais inconformadas. Raimundo Capela, um velho colega de Coimbra de Antero de Quental, aquando da morte deste, escrevia na Gazeta de Notícias, do Rio de Janeiro: "A união ou a fusão ibérica parecia-lhe e parecia a todos nós uma conveniência política e uma necessidade fisiológica" ${ }^{\prime \prime}(10)$.

Bom, a todos não pareceu, como adiante se verá, e a quem pareceu manifestou-se por formas diversas, consoante o momento. Inevitável será referir Antero que, neste aspecto como em tantos outros, foi veemente e polémico. No opúsculo que publicara dois meses após a revolução de 1868 que destronara a rainha espanhola ${ }^{(11)}$, apelava à "renúncia da nacionalidade" - "monstruosa conclusão" como lhe chamará mais tarde Teófilo Braga (na obra História das Ideias Republicanas em Portugal) - e a sua conferência do Casino de 1871 sobre as Causas da Decadência dos Povos Peninsulares nos últimos três séculos, rematava com o apelo à revolução em nome da paz e à federação republicana em nome da autonomia municipal. A decepção virá pelos anos 1873-1875, com o fracasso da república espanhola, o abandono, ou destruição mesmo do Programa dos Trabalhos para as Gerações Novas, o agravamento da doença depressiva. Em carta ao editor Wilhelm Storck (1887) o velho socialista relembrou a sua apologia da Federação Ibérica, ilusão da qual desistira à força de golpes brutais.

Oliveira Martins reflectiu também, e intensamente, sobre a questão do iberismo, explicitando Sérgio Campos Matos que o seu pensamento não foi iberista no sentido estritamente político mas que tem pontos de contacto com narrativas iberistas ${ }^{(12)}$. Entre 1869 e 1872, adepto do princípio federativo como possível síntese entre liberdade e autoridade,

(10) Cit. por Fran Paxêco, A Escola de Coimbra e a Dissolução do Romantismo, Lisboa, Casa Ventura Abrantes, Livraria Editor, 1917, p. 64.

(11) Portugal perante a Revolução de Espanha. Considerações sobre o Futuro da Política Portuguesa no ponto de vista da Democracia lbérica, Lisboa, Tipografia Portuguesa, 1868.

(12) Sérgio Campos Matos, "Iberismo e Identidade Nacional (1851-1910)", Clio, Revista do Centro de História da Universidade de Lisboa, nova série, vols. 14-15, 2006, p. 361 . 
acreditou na federação republicana ibérica após a revolução espanhola de 1868, como demonstra o seu tex to Do princípio federativo e sua aplicação à Península Hispânica (1869) ou ainda o artigo O golpe militar de 19 de Maio de 1870 e a ditadura militar (1870). Contudo, estas ideias vão-se paulatinamente matizando, vindo a recusar o federalismo proudhoniano no opúsculo Eleições (1878).

Na História da Civilização Ibérica (1879) defende que a origem dos povos ibéricos resulta da combinação dos berberes do Norte de África (líbio-fenícios) com a influência disciplinadora dos romanos, realça a ideia de génio ou alma peninsular, descortina para a Península movimentos decisivos para o futuro da humanidade e propõe uma união anfictiónica dos povos europeus. Já no Portugal Contemporâneo (1881) dedica um capítulo ao estudo do iberismo, considerando que, então, ele persistia no pensamento republicano federalista.

Contra a união com a Espanha pronuncia-se no jornal Repórter (1888) onde afirma que as três ambições de Espanha são Marrocos, Gibraltar e Portugal e, no ano seguinte, exprime a sua concepção de iberismo num texto com este título que publica no periódico O País: “União de pensamento e acção, independência de governo: eis, a nosso ver, a fórmula actual, sensata e prática de Iberismo".

Por sua vez, no artigo "Comércio Luso-Espanhol" (Repórter, Junho de 1888) critica o pouco vantajoso tratado comercial peninsular de 1883 e o seu promotor, o ministro espanhol Moret, cuja amizade por Portugal the fazia lembrar "a da macaca: tanto abraçou o filho que the arrombou o peito!". En Dezembro do ano seguinte, num artigo do Tempo, intitulado "Cá e Lá", a propósito dos receios dos espanhóis relativos à instauração da república em Portugal por influência da recentemente implantada no Brasil, Oliveira Martins admite a propensão iberista do republicanismo português mas afirma que a ela se opunha a vontade nacional autonómica, concluindo que "não se quer ser republicano porque não se quer ser ibérico".

Mas logo no mês seguinte, na ressaca do ultimato inglês, no texto "Alianças" (Tempo, 25 de Janeiro de 1890), no qual afirma que a Grã-Bretanha "como um vampiro, sugou-nos de vários modos", propõe uma aliança fraterna com o país vizinho:

"É para Espanha que havemos de voltar-nos. É com ela que devemos aliar as nossas forças no propósito de uma defesa comum, porque só 
com ela temos identidade de interesses, relaçōes progressivamente mais entranhadas, afinidades de tradições, comunidade de alma e irmandade de história. [...] Só a aliança das duas monarquias peninsulares é estável, natural, fecunda e duradoura. Desligados, vegetaremos sempre miseramente; aliados far-nos-emos respeitar pelos fortes, porque estaremos entre os primeiros ${ }^{\prime \prime(13)}$.

Quanto à federação latina - tão propalada pelos republicanos Oliveira Martins considerava-a então "um devaneio romântico".

Em 1891, juntamente com Sanches Moguel, deu corpo a um movimento académico peninsular com vista à aproximação das duas nações - a Liga Ibérica ou Fraternidade Ibérica. Mas também esta organização faliu e dela se dissociou cerca de dois anos depois, perto do fim da vida, quando publica as suas obras sobre os heróis de Avis (Filhos de D. João I; Vida de Nuno Álvares; O Principe Perfeito) obras criticadas, aliás, por aquele intelectual espanhol.

O pensamento de Oliveira Martins parece, assim, encerrar as duas faces do problema ibérico: a utópica e a distópica. Ele próprio admitia dois patriotismos: o ideal - o hispânico, e o real - o português ${ }^{(14)}$.

O aludido federalismo republicano difundiu-se com alguma intensidade a partir dos anos 1870, apresentando dois aspectos dignos de realce. Um consistia na afirmação generalizada do seu anti-iberismo, já que identificava iberismo com fusão ou anexação peninsular e reiterava a ideia de que a federação era justamente o oposto, isto é, a salvaguarda das nacionalidades. Veja-se a título de exemplo, entre tantos outros, o artigo de Teixeira Bastos publicado na Vanguarda, em 10 de Abril de 1881, intitulado "Não somos ibéricos" (15). A segunda vertente prendia-se com o corolário lógico da sua utopia de pacifismo universal, reforçado pela doutrina positivista que valorizava a cooperação entre os povos;

${ }^{(13)}$ Oliveira Martins, Politica e História, vol. II, Lisboa, Guimarães \& C. Editores, 1957, pp. 261-262.

${ }^{(14)} \mathrm{F}$. A. de Oliveira Martins, "O Iberismo de Oliveira Martins", in Oliveira Martins, Febo Moniz, Lisboa, Guimarães Editores, Lda., 4." ed., 1988, p. [37].

${ }^{(15)}$ Annadeu Carvalho Homem, "O tema do iberismo no republicanismo federalista português (1870-1910)", in O Federnlismo Europeu. História, Política e Utopia, Lisboa, Ediçōes Colibri, 2001, pp. 81-88; "O anti-iberismo dos republicanos radicais portugueses (1870-1910)", in Da Monarquia à República, Viseu, Palimage Editores, 2001, pp. 87-94. 
assim, cada vez mais, os seus teóricos defendiam ora os Estados Unidos da Europa ora, pelo menos, a grande federação latina que contrabalançaria outras federações de raça como o pangermanismo e o paneslavismo.

Nesta conformidade, avulta a figura de Teófilo Braga que defendeu as bases étnicas da nacionalidade no quadro da lei dos três estados, partindo do conceito romântico de raça no qual via o postulado comtiano da conciliação do Progresso com a Ordem. Assim, criou a (forçada) teoria do moçarabismo para sustentar a individualidade étnica do povo português e defendeu uma federação republicana de base etnológica, inspirado em Henriques Nogueira e no catalão Pi y Margall (As Nacionalidades, 1876). Sistema rígido e determinista, sem dúvida, mas que lhe forneceu certezas reconfortantes, face aos desânimos e decepções de Antero e Martins com quem manteve, aliás, acesas polémicas. Na obra Sistema de Sociologia (1884) condena a "união ibérica", entendendo esse conceito como exclusivo do unitarismo monárquico, quer português quer espanhol, o qual produzira, ao longo da história, a "morte das liberdades locais e a atrofia de uma raça activa", tendo a Inglaterra aproveitado ardilosamente as hostilidade mútuas. Portugal deveria ter centrado os seus acordos com a França que juntamente com a Espanha e a Itália constituíam os órgãos vitais da Civilização Ocidental, os estados mais adiantados para formarem uma federação. Todavia, a sua eucronia federativa latina tinha debilidades como o próprio reconhecia: a política francesa não se compatibilizava com a ideia de federalismo e os seus republicanos laboravam no erro unitarista. Curiosamente, por influência gaulesa, Teófilo e os seus correligionários optaram por essa solução, uma vez no poder.

Em 1894 publica A Pátria Portuguesa. O Território e a Raça que retoma as suas teorias de sempre: a fundamentação étnico-mesológica da nacionalidade portuguesa, sem esquecer as tradições e profecias nacionais; a excelência do federalismo; a confederação latina; e o culto da Pátria. Esta questão do patriotismo assumia então particular acuidade como se verifica no texto preliminar da referida obra que alude ao banquete que pela primeira vez reunira formalmente republicanos espanhóis e portugueses, realizado em 24 de Junho de 1893, em Badajoz, e que as faç̧ões monárquicas exploraram largamente como mais uma conspiração ibérica. Teófilo aproveita para transcrever o discurso que enviara já que não pudera estar presente: aí evidencia o equívoco que separava os dois povos mantendo entre eles uma "aversão implacável" - a união ibérica. 
Esta apenas interessava às dinastias, enquanto a república era esperança de paz, a paz peninsular que parecia estar sempre por un fio:

"Feita a república nos dois países, acabará essa ameaça permanente de invasão espanhola que traz Portugal acorrentado ao jugo espoliador e brutal da Inglaterra; e os dois Povos confederados tornarão a Espanha uma potência europeia, verdadeiro ponto de apoio da Confederação latina ou ocidental, em cujos povos ainda hoje existe a parte mais culta, moralizada e consciente.

[...] Diante deste ponto de vista mais avulta a situação irracional em que se acham em frente um do outro Portugal e Espanha, embaraçando-se e depauperando-se. Só poderemos sair dela, reconstituindo-nos pela República, única solução científica e em harmonia com a dignidade individual e com o estado da consciência moderna; enquanto ao passado reconhecendo a autonomia dos Estados ou naçôes peninsulares, e enquanto à aspiração hodierna federando-as em umn grande potência".

Magalhães Lima partilhou os ideais do seu mestre Teófilo Braga e ainda estudante traduziu Os Estados Unidos da Europa de Charles Lemmonier (1874). Destacou-se sobretudo na divulgação externa do ideário republicano-federalista e pacifista pelo que empreendeu numerosas viagens que a sua fortuna pessoal podia custear ${ }^{(16)}$. Além da federação ibérica de base municipalista (La Féderation Ibérique, 1893), fez também propaganda da confederação latina - uma União Mediterrânica inspirada no modelo do zollverein - nomeadamente na viagem que realizou durante seis meses pela Europa logo após o Ultimato, sob o lema "ou federado com Espanha ou escravos da Inglaterra" e sobre a qual escreveu a obra Pela Pátria e pela República (1890). Nascido no Rio de Janeiro, cidade que deixou ainda muito jovem, privou com os vultos mais importantes do republicanismo brasileiro ${ }^{(17)}$ os quais se manifestaram apoiantes da federação latina e, tal como outros federalistas portugueses, defendeu o alargamento desta associação supranacional ao Brasil. Logo após a implantação da república brasileira (1889), o prestigiado

(16) Maria Rita Lino Garnel, A República de Sebastião de Magalhães Lima, Lisboa, Livros Horizonte, 2004,

(17) Rangel Pestana, Benjamin Constant, Campos Sales, Lopes Trovão, José do Patrocínio, Assis Brasil, Rui Barbosa, entre outros. 
jornal que este publicista fundara no início da década de oitenta - O Século - far-se-á órgão apologético da confederação luso-brasileira e até da confederação ibero-americana, sendo também aí de realçar as contribuições de Latino Coelho.

Todavia, em plena guerra mundial, Magalhães Lima reajusta um pouco a sua utopia internacionalista, defendendo uma União Ocidental alargada aos anglo-saxões, cuja cultura se filiava em Roma, mãe comum, que triunfou sobre a sua eterna inimiga, a Barbárie Germânica. Esta federação anglo-latina centrada no Atlântico, com o fim da guerra, vai sobretudo realçar a confederação luso-brasileira. Em carta a Bettencourt Rodrigues (que com João de Barros também defendia a aproximação ao Brasil segundo o modelo confederal) já não fala em panlatinismo mas em panlusitanismo, na "nova e grande Lusitânia" que agora vira os olhos para o Atlântico ao qual portugueses e brasileiros passariam a chamar Mare Nostrum ${ }^{(18)}$.

Num quadro ideológico diverso, o pensamento de António Sardinha traz contributos fundamentais para esta análise. Em 1915, o grupo do Integralismo Lusitano organiza as Conferências da Liga Naval cujas actas publica no ano seguinte com o título A União Ibérica. A introdução da obra esclarece as razões do novo sobressalto: a escalada da propaganda ibérica em Espanha, na imprensa periódica, nos textos do político Juan Nido y Segalerva ${ }^{(19)}$ e do professor de Valladolid Vicente Gay, bem como nos discursos, e mesmo actos de Afonso XIII, sempre tão comentados em Portugal ${ }^{(20)}$. Apesar da predominância dos estímulos externos, os integralistas monárquicos não têm dúvidas quanto às responsabilidades do novo regime: "Os desvarios da República de Portugal alentam de novo a questão ibérica" ${ }^{\prime(21)}$. O seu entendimento

${ }^{118)}$ Magalhães Lima, Episódios da Minia Vida, Lisboa, Perspectivas \& Realidades [1927], s.d.

(19) Juan del Nido y Segalerva, La Unión lbérica. Estudo crítico, histórico de este problema formado con cuanto acerca de él han escrito los historiadores, asi portugueses como españoles, y los defensores de ella, Madrid, Tipografías de Prudencio P. de Velasco, 1914.

${ }^{(20)}$ Sobre os "perigos espanhóis" nos inícios da República veja-se Raul Brandão, Vale de Josafat, in Obras Completas, Lisboa, Relógio d'Água [1933], 2000, pp. 49-53.

(21) Frase inaugural da obra de compilação das conferências da Liga Naval, A Questão lbérica, Lisboa, Almeida, Miranda \& Sousa Ltd., 1916. 
da união ou federação peninsular é fortemente anti-utópica, afirmando com desdém que tal ideia radicava no "humanitarismo revolucionário e romântico", no "delírio democrático" que sonhava com os "conceitos retrógrados" de fraternidade universal, abolição das pátrias ou grande Família-Humanidade, como se isso fosse o bastante "para garantir a paz, gerar a abundância, a virtude", oferecer "um eldorado de encanto em permanente festim". A intenção dos integralistas é simples, apenas demonstrar que "Portugal tem tanta individualidade como Castela".

A esse propósito se subordina o texto inaugural - O Território e a Raça - de Sardinha, que apresenta óbvias semelhanças com o título do seu antípoda político Teófilo Braga, de quem aceita a tese da origem étnica da nacionalidade e da importância aglutinadora do municipalismo, recusando, obviamente, a conclusão da federação ibérica republicana. Ao apresentar o perigo ibérico como tema central, esta conferência da Liga Naval defende que a pátria tem que se reabilitar pela Ordem: "Só vivem os povos que sabem viver". Seguindo o credo integrista, exautora as doutrinas liberais e a maçonaria ("servidora desvelada da fusão ibérica") como a origem de todos os erros modernos, e afirma que são os nossos desvarios que escancarão as portas aos espanhóis, denunciando a traição do "estrangeiro do interior"(22). Ao atribuir à pátria uma realidade fisiológica - um corpo humano e una alma que é o génio da raça (ou razão afectiva do povo) - fica patente a sua concepção determinista orgânica. Curiosamente, baseia-se na obra do geógrafo anarquista Elisée Reclus (Nonvelle Géographie Universelle) e na do positivista José Augusto Coelho que, a seu ver, apenas "enferma do preconceito democrático" ${ }^{\prime 23)}$, para explicitar que é precisamente

${ }^{(22)} \mathrm{O}$ rol de intelectuais e políticos portugueses que culpabiliza é extenso: Gomes Freire, Fernandes Tomás, Mouzinho da Silveira, Alexandre Herculano, Oliveira Martins, Magalhäes Lima, entre outros, afirmando ainda: "Se um dia se quiser informar o processo do Constitucionalismo em Portugal, não carecemos de outra fonte de instrução. A questão ibérica é bastante" (p. 26). Idêntica condenação do século XIX e, consequentemente, do iberismo e dos seus presumíveis responsáveis, faria mais tarde Hipólito Raposo na obra Aula Régin, Porto, Livraria Civilização, 1936.

${ }^{(23)}$ José Augusto Coelho, Evolução Geral das Sociedades lbéricas, Lisboa, Livraria Moderna, 2 vols., 1909. Como o autor diz no prefácio, vai estudar as sociedades ibéricas "numa grande síntese sistemática e à luz da ciência moderna" para, após esta larga exposição, chegar à conclusão de que "o iberismo é um absurdo 
a geografia e a antropologia - o Meio e a População, o Território e a Raça - que tornam Portugal uma realidade inconfundível e persevera na diferenciação psicológica dos povos: os espanhóis guerreiros, saqueadores e místicos; os portugueses afectivos, missionários e líricos.

Todavia, durante o exílio em Espanha (1919-1921), o seu pensamento sofre alterações consideráveis. Escreve vários textos em revistas e jornais que viriam a ser compilados num livro póstumo - $\grave{A}$ Lareira de Castela (1943) - que pretendiam rectificar o seu "nacionalismo alarmado" de 1915 e denunciavam a "lenda negra" de cativeiro e opressão que o ultra-romantismo havia forjado. Mais ainda, Sardinha patenteava a sua fé na aproximação espiritual dos dois países peninsulares pela defesa do conceito de hispanismo, o qual se alargava ao de hispano-americanismo já que o destino de Portugal e de Espanha encontrava na América o seu prolongamento natural. Tais ideias seriam desenvolvidas em A Aliança Peninsular ${ }^{(24)}$, obra maior do seu utopismo hispanista publicada um mês antes da sua morte. Aí recupera as teses de aliança com Espanha de Oliveira Martins (bem como o seu conceito de "génio peninsular") e de Moniz Barreto formuladas no pós-ultimato ${ }^{(25)}$, explorando a metáfora deste último: retalhada e dividida a Península jamais deixará de ser o lenço de Verónica, "a estampa ensanguentada do nosso lento e irremediável suicídio"; vitupera o espectro do iberismo que considera uma "avantesma inconsciente saído dos conventículos da revolução" e "poderoso dissolvente" das relações luso-espanholas; explica a diferença psicológica dos povos peninsulares pelos conceitos de "sebastianismo" e "quixotismo" - dois ethos que individualizam mas não separam. Da mesma forma, a História e a Geografia individualizam mas também ampliam e completam, formando uma espécie de "supernacionalismo" ou soma de duas gloriosas pátrias que constitui a "Cabeça da Europa" cantada por Camões. A par do seu hispano-americanismo constata-se a recusa do latinismo pela expressa exclusão da França, país de quem

e que Portugal é uma nacionalidade com características nítidas e irredutíveis, de verdadeira e real independência".

(24) Teve duas edições portuguesas (1924 e 1930) e duas espanholas (1930 e 1939).

${ }^{(25)}$ Moniz Barreto, "A Situação Geral da Europa e a Política Exterior de Portugal", Revista de Portugal, Lisboa, n"19, Dez. 1891, pp. 81-104. 
os peninsulares sempre foram vítimas, não havendo entre os povos qualquer similitude moral.

Em suma, ao iberismo maçónico e ao europeísmo protestante contrapõe o Peninsularismo e o Hispanismo. A Hispano-América, a grande mãe Hispânia, une-se pelo Atlântico que pelo navalismo se torna o Mare Nostrum.

O seu brado é, pois: "Acima hispanos de ambas as margens do Atlântico".

O apelo é inequívoco mas, como já vimos, não é original, pese embora as óbvias diferenças ideológicas.

Assim, o teórico integralista contrapõe ao unitarismo e federalismo ibéricos a ligação das direitas de Portugal e de Espanha onde encontra correligionários à altura - Angel Ganivet; Ramiro de Maetzu; Vasquez Mella(26) O pan-hispanismo assume a fórmula da amizade peninsular consubstanciada na Festa da Raça que se passou a comemorar a 12 de Outubro. Nesse dia de 1924, realizou-se um banquete, curiosamente também em Badajoz, onde Sardinha discursou. Tal como as solidariedades republicanas, também as redes tradicionalistas funcionaram na Península, e em moldes operativos bem semelhantes.

Pelos breves exemplos apontados, verifica-se que a reflexão iberista em Portugal assumiu diversos matizes e repercutiu-se em várias ideologias ao longo das décadas; os próprios percursos mentais de numerosos doukrinadores patenteiam mudanças e metamorfoses. Alguns farão a apostasia do ideal, como Sampaio Bruno, que depois de defender o federalismo peninsular nos jornais O Norte Republicano e A Folha Nova, disso se penitenciou expressivamente - o tom é nitidamente confessional - na sua obra Os Modernos Publicistas Portugueses, patenteando a dialéctica utopia/distopia que a doutrina encerra:

"Eu já compartilhei daquela errada doutrina da federação peninsular como meio de se criar um grande Estado: a Ibéria, a opor à Inglaterra, à França, à Rússia, à China, se calhasse. Escrevi, a defender essa quimera, péssimos artigos, repletos de um patriotismo transviado. Publiquei-

(26) Figuras que elogia nos textos que constituem a obra $\grave{A}$ Lareira de Castela (aliás, a par de Charles Maurras, pese embora a contradição de Sardinha ao alinhar neste caso hispanismo e latinidade). Ramiro de Maetzu escreverá o prólogo para La Alianza Peninsular (1930). 
-os, inteiramente anónimos, no Norte Republicano, do Porto, aquando da celeuma contra o republicanismo propagandístico levantada pela imprudência das afirmações do federalismo ibérico feitas no Século por Alexandre da Conceição, o que autenticava da impopularidade da doutrina, que servia de arma de guerra nas mãos dos conservadores para desviarem dos revolucionários as simpatias do país. Desses artigos absurdos, os publiquei, com a rubrica do meu pseudónimo habitual, ao diante próximo, na Folha Nova, também do Porto. Penitencio-me. Bato com a caneta no almaço. Mea culpa. Mea magna culpa. Não ajuntarei: Mea maxima culpa, porque na minha consciência de escritor público, medíocre porém sincero, tenho outros pecados mais graves a expurgar.

Mas nem eu nem nenhum dos meus companheiros em federalismo republicano peninsular quisemos jamais que Portugal fosse, por via unitária ou por processo federativo, uma província de Espanha, como tranquilamente escreve essa enormidade indiscreta (que seria a precária realidade) Pi y Margall. Portugal: uma província de Espanha - nunca!

A minha utopia, a nossa utopia: era outra (tão ingénua e tão orgulhosa) bem diversa. O que nós queríamos parecia-nos - e era, de facto - o único modo de uma aproximação livre possível entre Portugal e Espanha, sem detrimento e sem diminuição, efectiva ou moral, sem menoscabo e sen perigo, para o nosso país. Mas concretamente não passava duma ilusão ainda"(27).

Apreender o fenómeno de adesão ao ideal ibérico sob a perspectiva quantitativa é impossível, compreender as suas variantes é complexo. Apesar de minoritária, esta ideia provocou ondas sucessivas de polémica, dominou a opinião pública durante mais de meio século, assumiu foros de questão nacional, mobilizou um largo espectro social, enfim, saltou para a rua. Como referiu Franco Nogueira, instalava-se o "fenómeno patológico" do iberismo ${ }^{(28)}$.

E muito mais volumosa do que a propaganda ibérica foi a de sentido contrário que, logo a partir dos anos 1850, se foi divulgando por todos os meios de comunicação. O maior caudal formou-se, naturalmente, nas páginas da imprensa periódica mas, a par dele, há a considerar uma vasta

(27) Sampaio Bruno, Os Modernos Publicistas Portugueses, Porto, Livraria Chardon de Lello \& Irmão Editores, [1906] 1987, pp. 113-114.

${ }^{(28)}$ Franco Nogueira, Juizo Final, Porto, Livraria Civilização Editora, 1992. 
literatura derramada em livros, opúsculos e folhetos, na narrativa e na ficção histórica, na oratória política e na parenética, na dramaturgia, na poesia e nos hinos. A mensagem não passava só pela palavra escrita e lida, mas também pela palavra ouvida e cantada, em cenários tão diversos como a igreja ou a escola, o teatro ou a festa popular. Suscitada por este clima, foi criada em 1861 a Associação $1 .^{\circ}$ de Dezembro, com Comissão Central em Lisboa e desdobrada em numerosas delegações locais, que inscreveu o ritual de comemoração da Restauração na liturgia cívica nacional, fomentou a criação de "lugares de memória" e reivindicou, sistematicamente, a reorganização militar do país. Revivesceu-se de forma inédita e reiterada a memória de 1580; a presentificação do domínio filipino produzia o receio de repetição da história e essa dominação representava o abismo cavado para sempre entre as duas nacionalidades; como pregava o Padre Almeida Ribeiro, num sermão de 1869, entre elas existia "o caos impermeável de Milton!"(29).

$\mathrm{O} 1^{\circ}$ de Dezembro passou a ser a data simbólica por excelência, comemorada de uma ponta à outra do país, ano após ano, embora suscitando, progressivamente, algum cepticismo e saturação, para o final do século ${ }^{(30)}$.

Impunha-se pois uma forte reacção à propaganda ibérica, quer a produzida internamente, quer a proveniente de Espanha, sempre tão persuasiva e aliciadora. Essa reacção gerou representações violentas que identificavam a união com a morte da pátria, o aniquilamento da nacionalidade. A cruzada anti-ibérica descreveu um futuro distópico, caracterizado pela opressão, pela tirania e pela miséria.

Apesar de constantemente se apelar à prudência para não se ofender o país vizinho, as visões produzidas sobre a Espanha e os espanhóis foram profundamente contundentes e pejorativas. $O$ objectivo era veicular a ideia da sua inferioridade moral por um lado, e a ameaça de invasão, por outro.

Assim, enfatizava-se o défice constitucional e o aviltamento do regime liberal de Espanha onde os pronunciamentos militares e os

(29) José Maria d'Almeida Ribeiro, Oração pela Feliz Restauração de Portugal no ano de 1640 pronunciada na Sé Patriarcal de Lisbon em o dia $1^{\circ}$ de Dezembro de 1868 , Lisboa, Tipografia de Castro Irmão, 1869, p. 24.

(30) Maria da Conceição Meireles Pereira, "O 1." de Dezembro - Memória e Liturgia Cívica na 2." Metade de Oitocentos", Revista de História das Ideias, vol. 28,2007 , pp. 129-167. 
fuzilamentos se sucediam como numa Babel política onde também não faltava o fanatismo religioso; os espanhóis surgiam com uma natureza profundamente cruel, sanguinária e desonesta, propícia à criminalidade e adequada à diversão nacional: a tauromaquia de morte. Por isso não eram raras as expressões que representavam a Espanha do garrote em perpétua "embriaguez sanguinária" e "vergonhosa barbárie", como "umla posta de sangue", a "África europeia", enfim o flagelo e opróbrio da humanidade em geral e "ferrete de ignomínia da Europa do século XIX", em particular. A sua educação era a "do curro", predominando a lei do Corão: "crê ou morre". Como expoentes da crueldade e tirania eram apresentados Filipe II, Torquemada e Claret ${ }^{(31)}$.

Evidentemente, estes traços de carácter contrastavam com os costumes brandos, liberais, indulgentes dos portugueses. Vejam-se os seguintes excertos:

"Entre Portugal e Castela não há montanhas, não há rios, não há mares que os separem: mas há uma distância infinita entre um e outro país que são os sentimentos humanitários" ${ }^{\prime \prime 2)}$.

"Conta os séculos que nos distanciam de ti pelos graus de civilização en que te sobrepujamos. Ainda neste ano assombraste o mundo com os teus fuzilamentos, com as tuas perseguições tirânicas, com as algemas que lançaste sobre a imprensa liberal: nós desenrolamos ante teus olhos a lei sublime da abolição da pena de morte, demos-te exemplo da manifestação libérrima do pensamento, congratulámo-nos com a protecção fraternal aos teus emigrados.

Quanto é diferente da tua a nossa vida constitucional!"(33).

A apregoada superioridade moral portuguesa não deixava de sublimar a consciência de uma inferioridade material, mesmo não sendo a Espanha uma nação de primeira grandeza no concerto europeu, e de exorcizar uma proximidade ameaçadora, como bem definiu a ironia de Eça:

(3) Maria da Conceição Meireles Pereira, "Relações entre Portugal e Espanha no $3^{\circ}$ quartel do século XIX - os aspectos cultural e económico", População e Socicdade, Porto, n. ${ }^{\circ}$ 6, 2000, pp. 104-105.

(32) A Opiniño, Lisboa, n 994, 25 Abr. 1860, p. 1.

(3) O Eco Portalegrense, n 19, 28 Dez. 1867, p. 1. 
"Sobre a Espanha sabem o meu pensamento [...]; detesto os encontros e abraços da panela de ferro com a panela de barro: detesto mais que se vá pedir esmola a um pobre e auxílio a um paralítico.

Detesto também o sistema militar da Espanha, e aquela sinistra colaboração de generais e fidalgos.

De resto, amo tudo, na Espanha. Somente gostava mais dela se ela estivesse na Rússia"(34).

Sem esquecer que os espanhóis também produziram representações negativas e até caricaturais dos portugueses, verifica-se que o nacionalismo português utilizou o "outro" como instrumento da construção identitária, gerando estereótipos e imagens colectivas que funcionam como elementos eficazes de diferenciação e de afirmação da própria identidade. Ao pôr a tónica na índole guerreira de Espanha e dos espanhóis, estes assumiram um carácter ofensivo de invasor, mobilizando as consciências para uma agressão, sempre mais fictícia do que real. Por isso, além da mitologia nacional de fundo medievo rica em símbolos, heróis, lendas e ritos, aliás intensamente convocada neste período, poder-se-á dizer que a identidade nacional portuguesa é também uma construção contemporânea, forjada quer no calor da instauração do regime liberal quer, posteriormente, ao longo da segunda metade de Oitocentos. Ignacio Chato Gonzalo apresenta a Espanha como o país que representou o papel do "outro" para a consciência nacional lusa, constituindo-se este antagonismo como o verdadeiro motor do nacionalismo reactivo português ${ }^{(35)}$. A instrumentalização política do iberismo, em que se inscrevia o tópico da ameaça espanhola, inibiu o estreitamento de laços mais profundos aos diversos níveis: económico, político-diplomático, cultural, frustrando políticas de valorização interpeninsular. Nuno Monteiro e António Costa Pinto defendem que o século XIX português foi marcado por dois nacionalismos sucessivos, o anti-francês e o anti-britânico ${ }^{(36)}$; talvez a estes se possa

(34) Distrito de Évora, n"13, 21 Fev. 1867, p. 2.

(35) Ignacio Chato Gonzalo, Las relaciontes entre España y Portugal a través de la diplomacia (1846-1910). La incidencia de la politica exterior en la construcción de la identidad nacional, Mérida, Editorial Regional de Extremadura, 2 tomos, 2004.

(36) Nuno Monteiro; António Costa Pinto, "Mitos Culturais e Identidade nacional Portuguesa", in António Costa Pinto (coord.), Portugal Contemporâneo, Madrid, Ediciones Sequitur, 2000, pp. 232-245. 
acrescentar o nacionalismo anti-espanhol ou, mais especificamente, anti-ibérico.

Apesar da historiografia espanhola insistir no cuidado que a sua política externa sempre teve relativamente a Portugal, evitando ferir susceptibilidades e matizando qualquer atitude expansiva e desafiadora, certo é que a Espanha não deixava de fazer frequentes apelos à unidade ibérica, alimentando ao longo de décadas o movimento iberista, embora destituído de intenções bélicas e anexionistas, só expressamente proclamadas a título esporádico e individual ${ }^{(37)}$. Todavia, a imprensa e a opinião pública portuguesas seguiam atenta e minuciosamente todo o movimento político do país vizinho. Se é verdade que não havia particular interesse pela cultura espanhola, é inegável que a situação política constituía tema diário dos periódicos portugueses dos diferentes quadrantes ideológicos. Impunha-se a sacramental pergunta: "O que há de Espanha?"

Este era o único país com quem Portugal mantinha uma extensa e vulnerável fronteira terrestre, a sua população era quase três vezes maior do que a portuguesa e a sua capacidade e predisposição militares inquestionavelmente superiores. Daí a ameaça pairar, sistematicamente, quer nas palavras, quer nos silêncios. Portugal parecia mentalizar-se para uma guerra que estava, em cada nova conjuntura, prestes a acontecer. Vejam-se os constantes apelos, da Associação $1^{\circ}$ de Dezembro à reorganização do exército e da marinha, ao armamento geral, à instrução militar generalizada, à criação de escolas de tiro, à própria formação de "milícias da independência".

E a guerra é, incontestavelmente, a mais distópica das situações. Mais ainda, a pior das guerras é aquela em que se prova a humilhação da derrota. Este tipo de conflito é apresentado sob o título "Se rebentasse a guerra com Espanha", pela Ilustraçāo Portuguesa, em três números consecutivos, entre Maio e Junho de $1906^{(38)}$.

Numa conjuntura de crescente rivalidade anglo-germânica, assiste-se ao lento processo de reafirmação da aliança luso-britânica todavia

(37) Um dos exemplos mais significativos é o folheto de Pio Gullon, La Fusión Ibérica, Madrid, Imprenta de Gabriel Allambra, 1861, 56 pp.

(38) Ilustraçāo Portuguesa. Revista Semanal de Acontecimentos da Vida Portuguesa, Lisboa, 2." série, n." 13, 21 Maio 1906, pp. 385-392; n.'14, 28 Maio 1906, pp. 417$-424 ;$ n. ${ }^{\circ} 15,4$ Jun. 1906, pp. 469-479. 
perturbada pela aproximação da Espanha de Afonso XIII à Inglaterra consumada na Conferência de Algeciras, justamente realizada entre Janeiro e Abril daquele ano. Apesar de as negociações terem como tema principal o Atlântico e Marrocos, o encontro levantou fortes suspeitas em Portugal sobre uma eventual aliança anglo-espanhola em detrimento da luso-britânica, tanto mais que eram consabidas as afinidades entre a Espanha e a Alemanha.

Apesar do título deste artigo configurar uma situação não real mas imaginada, e não obstante aí se afirmar que as circunstâncias repeliam a "agoirenta previsão" da guerra "para os recuados domínios do improvável", o texto sublinha a sua existência enraizada no imaginário português. Atente-se nas palavras da Ilustração: "Com uma insistência três vezes secular, e com a imperecível radicação dum carácter étnico, a eventualidade, a vaga antevisão de um conflito armado com a Espanha aninhou-se na alma nacional e constitui, íntima, profunda, uma das mais instintivas superstições do povo" ${ }^{\prime \prime 39}$.

A narrativa assume a forma de uma entrevista a um ilustre mas anónimo general reformado que desenrola a guerra ante os nossos olhos através de descrições vívidas, apoiadas em cinco gravuras ${ }^{(40)}$, 33 fotografias ${ }^{(41)}$ e dois mapas de operações militares ${ }^{(42)}$, sendo todas as figuras acompanhadas de legendas.

(39) Ilustração Portuguesa. Revista Semanal de Acontecimentos da Vida Portuguesa, Lisboa, 2." série, n." 13, 2 Maio 1906, p. 386.

(40) Além da gravura que inicia o texto nos três números da revista, as restantes representam o general a ser entrevistado no seu gabinete de trabalho; o rei com o seu estado-maior a passar revista às tropas; um oficial a ser morto a tiro entre uma multidão; o general Pinheiro, com o príncipe real e o estado-maior a assistirem ao desenrolar da batalha de Celorico.

(41) Uma das fotografias é manipulada, representando a fachada do jornal O Dia com projecções luminosas nas suas janelas de "telegramas dando conta do assalto à nossa legação em Madrid". As outras representam maioritariamente soldados - portugueses e espanhóis - em cenas de exterior, provavelmente em treinos e operações de rotina, sendo aqui enquadradas de forma a esses exercícios parecerem em contexto de guerra.

(42) Um é o mapa da batalha da Cerdeira onde se representa a retirada da infantaria portuguesa face às forças da infantaria e cavalaria espanholas. O outro intitula se "Planta da Batalha Hipotética de Celorico". 
O primeiro passo seria a mobilização. Logo aqui começam as dificuldades pois a arte marcial recebera do modelo alemão "uma ingestão de ciência excessiva" que poucos, e dificilmente os portugueses podiam acompanhar. Apesar de alguma desactualização, o ensino militar ganhara qualidade mas as limitações orçamentais reduziram os efectivos, isto é, faltavam os soldados. Por sua vez, a Espanha sofria do mal inverso: carecia de oficiais em virtude da guerra de $C u b a$. $O$ velho general evidenciava a inferioridade militar portuguesa e a mobilização seria bem mais lenta do que em Espanha onde vigorava o sistema de "tarjetas de cantina". Quanto ao teatro de guerra, a prioridade era dada à fronteira da Beira - as entradas dos vales do Mondego e do Tejo - pois se caíssem em posse do inimigo abriam-lhe o caminho para Lisboa. Neste cenário o general distribuía as divisões, brigadas e regimentos de infantaria pelas sedes de Lamego, Guarda, Viseu, Covilhã e Penamacor. Concedendo que este pessoal se apresentava nos prazos fixados, o que era altamente improvável, difícil seria estabelecer os depósitos para fardar, armar e municiar os soldados, bem como passar-se as requisições de animais e veículos quando nada estava ensaiado nesse sentido. Quanto à cavalaria, a primeira defesa poderia ser feita apenas por dois regimentos contanto que estes tivessem pessoal e... cavalos. Entretanto, são nomeados para comandar o exército do norte o general Almeida Cibrão, e para a fronteira o general Almeida Pinheiro.

Não falta a revista real às tropas, ao som do hino nacional. Além do seu estado-maior, acompanham o monarca o infante $\mathrm{D}$. Afonso e o príncipe real que, ao passar a cavalaria, segue-a com a sua arma pois fora determinado que participasse no conflito. As forças espanholas alcançam primeiro a fronteira e entram em território português sem entraves pois o planalto entre o Douro e Sabugal estava sob vigia do regimento 7 de cavalaria que não passava de "um esqueleto". Face a este revés, o general Cibrão instala o quartel-general na Guarda e, em prejuízo da coesão estratégica, envia dois batalhóes para a raia, um para o Sabugal e outro para Vilar Formoso. Mas um deles não chega ao destino pois ficara retido num centro industrial - a Covilhã - onde a ameaça de falta de braços faz estalar um movimento contra a guerra, juntando-se de noite uma "turbamulta de rotos, pregando clamorosamente a paz, ao mesmo tempo açulados por socialistas e capitaneados por fanáticos"; um corajoso oficial ainda tenta restabelecer a disciplina mas é imediatamente morto a tiro. Entretanto, a guerra prossegue. As tropas portuguesas avançavam 
lentamente pelas aldeias onde as populações, com uma espontaneidade cativante, lhes oferecem víveres, bebidas, animais de tracção e veículos de todo o tipo - era "o desvelado impulso do patriotismo nacional". Mas estes bravos homens, depois de graves perdas, têm de retroceder pois a cavalaria espanhola invadira o planalto e uma brigada concentrara-se a leste de Vilar Formoso com a mira de se apoderar do caminho-de-ferro. Felizmente, dois oficiais saídos da Guarda em missão de reconhecimento tinham feito explodir o grande viaduto ferroviário sobre o Côa. Todavia, este obstáculo não foi insuperável para o invasor porque no Verão o rio é transponível em vários pontos. As forças espanholas continuavam a avançar e aproximam-se da aldeia de Cerdeira, local estratégico onde a linha-férrea se cruza com dois eixos viários provenientes da fronteira e para onde os portugueses também se dirigem. "Aqui um rijo recontro torna-se então inevitável". E a batalha da Cerdeira é detalhadamente descrita, realçando-se a inferioridade numérica dos lusos, na proporção de um para três. Apesar da resistência heróica dos portugueses, sempre à espera da chegada de reforços, quem chega primeiro são os espanhóis que cortam a retirada e envolvem a Guarda pela rede de estradas e caminhos que a circundam. Segundo o testemunho de um desertor salvo de morrer afogado pelos portugueses, as hostes adversárias estavam bem equipadas, tinham inclusivamente automóveis para os trabalhos de reconhecimento, e totalizavam "vinte e tantos mil homens contra os nossos doze mil".

Impunha-se a retirada para Celorico, mas o inimigo antecipara-se, dominava posições chave e continuava a avançar com facilidade ante o pânico dos aldeões que começavam a debandar. Apesar do enorme esforço, as posições portuguesas ficam sempre escassamente defendidas; os contingentes não conseguem dominar tamanhas extensões e configurações do terreno. Dá-se a batalha de Celorico, que se traduz numa rotunda derrota não obstante os prodígios de valentia dos portugueses, enfatizando o texto o dramatismo da peleja: "Por toda a parte os nossos soldados, por fim, cedem, deixando, às centenas, os cadáveres em cachos pendurados pelas escarpas, e de heróicos farrapos de carne em sangue juncada tragicamente a penedia! ${ }^{\prime \prime(43)}$.

(43) Ilustração Portuguesa. Revista Semanal de Acontecimentos da Vida Portuguesa, Lisboa, 2." série, n. 15,4 Jun. 1906, p. 477. 
Os espanhóis tornam-se pois, rápida e fatalmente, senhores das estratégicas vias rápidas de comunicação: os caminhos-de-ferro das duas Beiras. A derrota está consumada e o país devassado.

A refrega bélica com Espanha também se projectou na literatura. Eça de Queirós interessou-se pelo tema e redigiu o conto A Catástrofe (por volta de 1885), derivado de uma obra maior a que pretendia dar o título A Batalha do Caia mas que terá sido aconselhado a abandonar. Só publicado em 1925, A Catástrofe desenvolve a ideia da redenção pela humilhação belicista infligida por um exército invasor cuja nacionalidade não revela (ao contrário do projecto de $A$ Batalha do Caia) mas que era óbvia. Ao estado de calamidade do país contrapunha o desastre da guerra como gerador de catarse e renascimento. $\mathrm{O}$ assunto, aliás, perpassa outras vezes na sua obra. Lembramo-nos bem das intervenções do Ega, em Os Maias:

“- Portugal não necessita reformas, Cohen, Portugal o que precisa é a invasão espanhola. [...]

- Sovados, humilhados, arrasados, escalavrados, tínhamos de fazer um esforço desesperado para viver. [...] E recomeçava-se uma história nova, um outro Portugal, um Portugal sério e inteligente, forte e decente, estudando, pensando, fazendo civilização como outrora...

Meninos, nada regenera uma nação como uma medonha tareia... Oh! Deus de Ourique, manda-nos o castelhano"(44).

Da guerra imaginada passemos à guerra real. As ambiguidades dos republicanos portugueses em relação ao país vizinho abundavam nesta época, produzindo representações contraditórias do relacionamento peninsular. A imprensa incidia no "renascimento espanhol", mais concretamente do seu espírito guerreiro(45), tendo já em 1913, Leote do Rego, em entrevista ao Século, abordado o assunto, afirmando que Portugal não deveria ficar indiferente a esse facto, embora não pretendesse insinuar que a Espanha tivesse em vista invadir-nos.

${ }^{(44)}$ Eça de Queiroz, Os Maias. Episódios da Vida Romântica, Lisboa, Edição "Livros do Brasil", 28." edição, s.d., pp. 167-168.

(45) Victor Falcão, Cartas de Espanha, Braga, Livraria Escolar-Editora, 1915. Trata-se da compilação de crónicas publicadas em $O$ Século. 
A entrada no $1 .^{\circ}$ conflito mundial afigurou-se imperiosa ao partido de Afonso Costa como forma de afirmação da República, do Império e da Nacionalidade. Embora não se pretenda aqui analisar as razões da participação portuguesa na guerra, a questão da nacionalidade ou autonomia prendia-se novamente com Espanha, isto é, com o reconhecimento internacional que o país poderia adquirir face à Espanha neutral. João Chagas afirma-o peremptoriamente:

“Há um aspecto, porém, desta questão que sobre todos me apaixona $\mathrm{e}$ que é a situação de alta superioridade moral em que a nossa participação na guerra nos coloca ao lado da retrógrada e reaccionária Espanha. Este país interpôs-se entre nós e a Europa e mal nos deixa ver. O movimento generoso e corajoso da nossa entrada numa guerra de defesa europeia, enquanto a Espanha se encolhe numa neutralidade egoísta e duvidosa, fará ver à Europa o que ela não viu ainda, isto é, que ao lado dessa nação, uma outra existe diferente e melhor. Pela primeira vez sairemos da lenda apagada da nossa história e fundaremos uma personalidade, enquanto a Espanha verá subverter-se a sua. E assim tiraremos à face do mundo a mais brilhante desforra do que ela nos fez. Quando a vitória vier, à custa do mais tremendo sacrifício humano que se conhece, a civilização há-de dar o balanço dos esforços que a serviram, a Espanha ficará sendo o último país da Europa, e do lado de cá da negra península haverá un clarão, que seremos nós. E a nossa autonomia será um facto nunca mais contestado e nunca mais a Espanha ousará voltar olhos cobiçosos para nós. A nossa participação na guerra é um novo Aljubarrota, em que a Espanha não entra senão com a sua sombra, mas em que ficará outra vez vencida - de vez!"(46).

E o militar Joaquim Ribeiro explicou desta forma a necessidade da intervenção: "Indo garantiríamos, pelo menos, a nossa independência, o nosso domínio colonial, e conseguíamos uma situação que nos permitiria confiar no futuro, deixando a Espanha de constituir, para nós, um perigo" ${ }^{\prime(47)}$.

(46) João Chagas, Diário. 1914, Lisboa, Parceria António Maria Pereira Livraria Editora, 1929, pp. 375-376.

(47) Joaquim Ribeiro, Na Guerra. Depoimento dum voluntário, Lisboa, Portugal-Brasil Lda, s.d. [1919], p. 18. 
Com efeito, após 1910, manteve-se o clima de tensão entre os dois países peninsulares. Os monárquicos portugueses exilaram-se na Galiza e de lá saíram as incursões couceiristas; Afonso XIII e os seus executivos jogaram uma política ambígua a esse respeito; a imprensa lusa continuava a dar protagonismo ao país vizinho; enfim o "perigo espanhol", ora mais fictício ora mais real, como tão bem estudou Hipólito de la Torre Gómez, pairava no imaginário dos portugueses e, sobretudo, dos republicanos no poder. Isto não anula a realidade inversa, isto é, o "perigo português" consubstanciado nos receios de contágio republicano em Espanha, a possibilidade de entrada de Portugal na guerra e consequente ingerência militar da Inglaterra em solo peninsular, entre outros aspectos.

Mas a partir de finais de 1915, por um golpe não de mágica mas de estratégia política, ambos os "perigos" vão-se dissipando nos respectivos discursos e imprensas governamentais. Portugal entra na guerra em Março de 1916 com a indispensável anuência tácita da Espanha, país cujo governo passa a ser chefiado por Romanones, um político de inclinação aliadófila que coloca como ministro em Lisboa o amigo pessoal López Muñoz. A Espanha neutral não podia estar de costas viradas ao Portugal beligerante; havia que harmonizar políticas e interesses.

En inícios de 1917 este movimento que visava a aproximação dos dois países assumiu contornos mais nítidos, pela mediatização que do assunto fez o jornal madrileno El Imparcial dirigido por Félix Lorenzo que se deslocou a Lisboa para inaugurar uma delegação do periódico. "Harmonia ibérica" foi o nome assumido por esta campanha que congregou políticos destacados dos dois países, directores de jornais, reitores universitários; foi objecto de discursos políticos, conferências e múltiplos trabalhos jornalísticos; visitas e encontros de Estado, atribuição de condecorações ${ }^{(48)}$.

Embora Bernardino Machado tentasse explicar à opinião pública a natureza desta aproximação através de uma fórmula simples - "Aliança com a Inglaterra, fraternidade com o Brasil e amizade com a Espanha" - à excepção da imprensa governamental, especialmente $O$ Mundo, tanto a republicana como a monárquica fustigaram com veemência a suspeita campanha do El limparcial. Certo é que a "Harmonia Ibérica"

${ }^{448)}$ António José Queirós, O Jornal Portuense "A Montanha" e as Relaçöes Luso-Espanholas (1911-1926), Amarante, Edições do Tâmega, 1997, p. 110 ss. 
durou pouco, mais ou menos até Junho de 1917, mas quem assim o determinou foi fundamentalmente o lado espanhol. Em Abril, o governo de Romanones é substituído e sucedem-lhe outros mais consonantes com a "neutralidade germanófila"; em Junho é a vez do ministro espanhol abandonar a legação de Lisbòa e Félix Lorenzo a direcção do seu jornal.

Nem a política de Lisboa, nem a de Madrid entraram ingenuamente neste enlace de conveniência, mas sob o ponto de vista do imaginário português é curioso realçar como a questão espanhola continuava a ser um acutilante instrumento político, um tema fracturante. A imprensa lusa denunciava com insistência os intuitos conquistadores dos espanhóis, reiterava que os dois povos continuariam a odiar-se cordialmente, cada um em sua casa. A Montanha, jornal afecto ao próprio PRP, alertava em Abril de 1917, para a brotoeja do neo-iberismo que se expandia no país como uma verdadeira epidemia ${ }^{(49)}$. Para só citar outro exemplo, refira-se o acompanhamento que da "Harmonia Ibérica" fez Homem Cristo, numa exaltada série de artigos publicados no periódico $O$ de Aveiro, entre Março de 1916 e Junho de 1917. Na sua óptica, todos querem a amizade com a Espanha mas "a ideia dominante e obsidente" daquele país "é apoderar-se de Portugal", pelo que exorta à organização de um grande exército, concluindo, que "uma guerra próxima com Espanha, se não é provável, é possível" (50). Aliás, "harmonia ibérica" era um eufemismo, significava simplesmente "união ibérica"(51).

Como seria de esperar, Félix Lorenzo também não escapou e começou a falar-se de um livro pouco simpático sobre Portugal que publicara há pouco tempo. Com efeito, em 1915, saíra em Madrid sob o título Portugal (Cinco Años de República). Impresiones de un periodista español, um livro pouco recomendável para incentivar a amizade peninsular. O seu relato baseava-se em três curtas visitas que fizera a Portugal: uma em 6 de Outubro de 1910; outra em Julho de 1912; a última em Maio de 1915. Da primeira guardava as melhores impressões, elogiando a república que o país inteiro reclamava e soubera instalar um clina de tranquilidade. A segunda viagem decorre no rescaldo da $2^{a}$ incursão monárquica e dá conta da campanha contra Espanha que a imprensa

(49) António José Queirós, O Jornal Portuense "A Montanha" e as Relações Luso-Espanholas (1911-1926), Amarante, Ediçōes do Tâmega, 1997, p. 117.

(50) "Coisas de Espanha", O de Aveiro, 8 Jul. 1917.

(51) "A Harmonia Ibérica", O de Aveiro, 13 Maio 1917. 
republicana promovia de forma sistemática e violenta, obsessivamente dominada pela ideia da invasão e conquista espanhola:

"Si en Madrid hubiese un hombre capaz de hablar en serio de la conquista de Portugal, no se le reiría en las barbas todo el mundo?

Puede haber cosa más absurda, más fuera de ocasión, más infundada?

Pues en Lisboa se cree a pies juntillos por una grande parte del pueblo y por una parte de la prensa que el momento actual solo es un avance del plan de conquista que España prepara desde hace mucho tiempo"(52).

Descreve então Lisboa como a cabeça tumultuosa de um centro anémico, dominado pela carbonária e por turbas exaltadas; na capital aumentava até a prostituição e surgiam antros de pornografia. A sua última visita coincidiu com o derrube de Pimenta de Castro e Lorenzo insiste em ver Lisboa como um clube de paixões explosivas, onde imperavam a violência e as prisões, abundavam os fabricantes de bombas, sindicalistas e anarquistas semeavam a instabilidade, enfim, onde "a paz estava presa por alfinetes".

Por isso, a situação de Portugal em Maio de 1915, a seu ver, era lamentável e o único remédio que se impunha era a "compenetração" com Espanha - compenetração é o termo que emprega neste livro e depois nos seus textos do Imparcial, aparecendo também em outros discursos espanhóis da altura.

Como se viu, à paz perpétua e promessa de felicidade plena das utopias iberistas, parece ter-se contraposto a distopia ibérica projectada na ameaça de guerra iminente, no temor da sujeição opressiva, no receio da fusão humilhante. No limiar do século XX, o catalão Ribera i Rovira, que defendia uma Ibéria una e trina resultante da federação hispânica das três nacionalidades autónomas - Portugal, Castela e Catalunha -, no seu livro lberisme atribuiu a culpa do fracasso do ideal justamente à natureza utópica dos projectos, isto é, as ideias iberistas, sempre utópicas, afastaram-se da realidade e não obedeceram senão a abstracções ${ }^{(53)}$.

${ }^{(52)}$ Félix Lorenzo, Portugal (Cinco Años de República). Impresiones de un periodista español, Madrid, 1915, p. 78.

${ }^{(53)}$ Ignasi Ribera i Rovira, Iberisme, Barcelona, 1907. (Capítulo VII: Utopias iberistes). 
A variedade de conceitos de iberismo, ora político, ora cultural ora ainda económico, dos regimes e ideologias que o poderiam viabilizar, as alterações de que foi alvo no pensamento de numerosos autores, a diversidade lexical que assumiu em função das conjunturas que polarizavam recursos ou dificuldades suscitam algumas interrogações finais.

Iberismo, federalismo ibérico, panlatinismo, hispanismo, compenetração peninsular, harmonia ibérica, neo-iberismo, aliança peninsular, foram alguns conceitos utilizados no contexto histórico em análise. Que significavam? Avatares de uma ideia ou consciência da intangibilidade de uma fórmula para o entendimento peninsular?

A doutrinação iberista propiciou a aspiração supranacional formulada na confederação alargada à América do Sul?

O nacionalismo português oitocentista também se alimentou da questão ibérica, construindo a identidade nacional em oposição ao "outro", o vizinho ameaçador, ou a sua origem é predominantemente anti-francesa decorrente das invasões napoleónicas e anti-britânica em função da histórica e asfixiadora aliança luso-inglesa?

As representações utópicas e distópicas do iberismo, configurando "um dos tópicos mobilizadores do debate público sobre a nação, o seu presente, passado e futuro [...] no centro de toda uma reflexão acerca do percurso histórico nacional, do 'carácter' dos Portugueses"(5ł), terão contribuído para pensar o país na perspectiva do binómio decadência / / regeneração?

(54) Sérgio Campos Matos, "Conceitos de Iberismo em Portugal", Revista de História das Ideias, vol. 28, 2007, p. 169. 
